\title{
A Leaf from Algonquin Park: Preliminary findings of a content analysis of information practice stereotypes in the documentary trail of a world-famous provincial park (1890-2018)
}

\begin{abstract}
Résumé:
This longitudinal, retrospective study presents preliminary findings from an in-progress content analysis of the documentary paper trail associated with Algonquin Provincial Park. The project seeks to understand how local residents, visitors and Indigenous people of the Algonquin Park area are represented in published accounts of people who have come into contact with them, and how those representations reflect the actual information seeking behaviors of, and stereotypes associated with, these rural populations.
\end{abstract}

\section{Background:}

Using ethnographic methods in my research, I examine familiar experiences of everyday life in remote and rural places looking for undocumented, experience-based sources of information. A growing movement, spurred on by the 2003 UNESCO Convention on Safeguarding Intangible Cultural Heritage (ICH) (UNESCO, 2003), and by Savolainen's research in library and information studies research, suggest that elevating common, everyday experiences and information sources like this above the trivial is a worthwhile exercise (Savolainen, 2008). It's certainly becoming more popular. Activities with these characteristics include, for example, rituals and ceremonies, beliefs, languages, performing arts, craftsmanship, and importantly, stories and tales.

While studying information practices in a small remote and rural community, I came across an example of a well-worn, almost folkloric tale of poverty. It's so common, in fact, that I heard variations on the theme at least three times during my doctoral data collection. It goes like this: When I was a child, we made the best of things. I had <insert number here - often more than $10>$ siblings, and we couldn't afford enough good clothes for everyone to go to $<\mathrm{church} / \mathrm{school}>$ at the same time, so we took turns wearing the good clothes we did have. Everyone got to go: my brother/sister went first, then it was my turn next time.

It's a good story. By the time I heard it the third time, I believed on a balance of probabilities each version was likely truthful, at least in essence. Until the day I saw the story of a specific individual published in a Canadian best-selling non-fiction book (Corbett, 2001) at the same time as I coincidentally had in my possession copies of school records to verify attendance. This particular story turned out to be a tall tale. The siblings all attended school together at the same time.

\section{The information problem:}

This story highlights how outside perceptions of life in rural places often differ dramatically from the actual, insider, lived reality. It is not hard to see how the implications of telling and 
retelling stories like this - the ones that live on the edge between truth and fiction - contributes to our (mis)perceptions of the information practices of the people represented in the stories.

Nowhere is the contrast between perception and reality more evident than in the context of one of the most pervasive stereotypes of remote and rural living: that the people who live in these locales are somehow a homogeneous group of simple, uneducated, destitute, or hillbillyish folk. While that may sound hyperbolic, sadly, pejorative characterizations are common and not limited just to popular belief. Library and information science (LIS) researchers unwittingly fall prey to similar questionable assumptions when they unfairly apply the term 'information poor' to groups of people - including rural residents - who appear to lack basic information skills, literacy skills, access to technology, or the ability to use it (Haider \& Bawden, 2007). Evidencebased library and information research is beginning to challenge these assumptions, showing that rural residents actually exhibit a number of psycho-social characteristics that make them resilient and sophisticated consumers and producers of information in their own right (Hersberger, 2013; Pollak, 2016).

Although the population at the heart of this story is virtually invisible on a global scale, they are located adjacent to and inextricably connected with Algonquin Provincial Park which this year celebrates its 125th anniversary. Much loved at home and renowned abroad, the documentary record is littered with references to the park, to the people who visit, and to the people who live nearby, including the First Nations people - the Algonquins of Ontario - who are namesakes for the park, and who are currently negotiating the province's first modern day constitutionally protected treaty and land claim. This proximity, notoriety and the documentary trail it has left behind in the public record creates a perfect opportunity to explore how the large, disparate group of travelers who visit the area for a short time and then leave perceive the people who live in this region.

\section{Research Design \& Questions:}

Best described as an historical research project conducted longitudinally, retrospectively and using trace measures, this study asks:

- How are local residents, visitors and indigenous people of the Algonquin Park area represented in published accounts of people who have come into contact with them?

- How do those representations reflect the actual information seeking behaviors of, and stereotypes associated with, these rural populations?

\section{Data Collection \& Analysis:}

Data collection examines primary and secondary records relating to Algonquin Park, Canada's oldest provincial forest reserve between the years 1890-2018. Records are drawn from a variety of publication formats (serial publications, news and images, fiction and filmography, ephemera etc.) and sourced from academic databases, and provincial and national archives. Content analysis identifies and develops thematic patterns that speak to stereotypes and representation in the printed record. Following Robinson's methodology (Robinson, 2006), each item retrieved is coded to describe the content according to three major facets: its bibliographic characteristics (where, when and by whom it was authored/published, size and type of item), the content of the item (topic, specificity, details about the main actors, authorial voice), and framing (stereotypes, attitudes, tone of article, information skills represented). 
Preliminary research and ongoing analysis has examined about one quarter of the roughly 550 databases targeted for this study. Of the approximately 3000 items retrieved thus far, only twenty contain content referring to Indigenous people. Analysis is showing gaps in representation of non-indigenous local residents as well, who are also largely overlooked in discussions about the park, despite being integral to it's functioning on a blue-collar level. Both populations are occasionally characterized negatively. These findings offer some early insight into the magnitude of the disparity in representation of remote, rural, and indigenous residents and their stories in the awareness of people who visit the area.

Although stories like the one that opened this abstract are shared orally and frequently in the Ottawa Valley area among locals, and though they may occasionally even be recorded in print and leave the community as this one did, initial analysis suggests that a great many everyday stories of work and family simply never make it outside the community or into the public record at all. Why this gap exists, and consequently, why these populations and their information behaviors may be perceived or characterized as lacking, appears to be attributable at least in part to the fact that we seldom hear about or go looking for information about them.

\section{References:}

Corbett, R. (2001). The Last Guide: A Story of Fish and Love. Ottawa, Ontario: Glen Ivy Media.

Haider, J., \& Bawden, D. (2007). Conceptions of "information poverty" in LIS: a discourse analysis. Journal of Documentation, 63(4), 534-557.

Hersberger, J. (2013). Resilience theory, information behaviour, and social support in everyday life. In Proceedings of the Annual Conference of CAIS / Actes du congrès annuel de l'ACSI (Vol. 0). Fredericton, New Brunswick. Retrieved from http://www.caisacsi.ca/ojs/index.php/cais/article/view/273

Isah, E. E. (2008). The information practices of physicians in clinical practice. Information Research, 13(4), 41-41.

Leckie, G. J., Pettigrew, K. E., \& Sylvain, C. (1996). Modeling the information seeking of professionals: A general model derived from research on engineers, health care professionals, and lawyers. The Library Quarterly, 66(2), 161-193.

Palmer, C. L., \& Neumann, L. J. (2002). The information work of interdisciplinary humanities scholars: Exploration and translation. The Library Quarterly, 72(1), 85-117.

Pollak, A. (2016). Information seeking and use in the context of minimalist lifestyles. Journal of Documentation, 72(6), 1228-1250. https://doi.org/10.1108/JD-03-2016-0035

Savolainen, R. (2008). Everyday information practices: A social phenomenological perspective. Lanham, Md.: Scarecrow Press. 
UNESCO. (2003). Convention for safeguarding intangible cultural heritage. Paris, France: UNESCO. Retrieved from http://www.unesco.org/new/en/santiago/culture/intangibleheritage/convention-intangible-cultural-heritage/ 